\title{
On-campus, distance or online? Influences on student decision-making about study modes at university
}

\author{
Matthew Bailey, Maree Gosper \\ Macquarie University, Sydney, Australia \\ Dirk Ifenthaler \\ University of Mannheim, Germany \\ Cheryl Ware, Mandy Kretzschema \\ Macquarie University, Sydney, Australia
}

\begin{abstract}
This article examines the choices students make when deciding the mode of study they will enrol in for university. It expands on previous work in the field by surveying 744 Faculty of Arts students at an Australian university who had the choice of enrolling in one of three study modes: on-campus, distance or purely online. Influences on enrolment mode were categorised into six factors: personal, logistics, teaching and learning, learning support, environment, and advice and marketing. Significant differences in influence were found between the three cohorts of students, while the teaching and learning and logistics factors were found to be the most influential for all cohorts. The findings of this research offer administrators, learning and teaching support staff, and academics important information that can be used to tailor the delivery of teaching and services to the varying needs of different cohorts.
\end{abstract}

\section{Introduction}

Online education has changed the ways that students study and has redrawn the competitive framework of the tertiary education sector (Andrews \& Tynan, 2012). Reductions to government funding have encouraged universities to explore new income streams (Bradley, 2008; Currie, 2002; de Zilwa, 2010), with the recruitment of students into online learning programs identified as one avenue of growth (Allen \& Seaman, 2011; Ziguras \& McBurnie, 2011). The expansion of technology-enabled solutions and platforms to run such programs has also encouraged their proliferation (Lee, 2015; Liaw, Huang, \& Chen, 2007; Moore, 2003). In this environment, it is becoming increasingly important to understand the decision-making processes that students go through when enrolling in higher education courses. As increasing numbers of institutions offer subjects and courses through online and blended delivery modes, competitive advantages will accrue to those that better understand why students choose different modes of study. Further, engaging with students to explore the reasons and motivations for study mode choice can enable universities to improve the student experience by tailoring delivery and support services to student needs. This article examines why students choose particular study modes when they commence their degree, with the premise that flexibility is both important to students and increasingly prevalent in the sector.

\section{Theoretical background}

Online learning has expanded access to higher education. Although there have been many successful operating models of distance education, the connectivity and immediacy of online learning has opened the field to far more institutions and students (Bates, 2005; Dobozy \& Ifenthaler, 2014; Ifenthaler, BellinMularski, \& Mah, 2015). Further, the technologies involved are increasingly being utilised for blended learning, which combines features of online instruction with face-to-face learning (Lefoe \& Albury, 2004; Lefoe \& Hedberg, 2006; Woo et al., 2008). This has implications for the ways that higher education institutions compete for students, position their offerings, resource their learning and teaching, cater to student interest and demand, and meet the expectations of a broad range of students studying through a variety of pure or blended modes of delivery.

As a result, the reasons for choosing different study modes and the choices students make when entering tertiary education have received considerable scholarly attention. Indeed, Hagel and Shaw (2010) argue 
that study mode is the most important focus for students, in terms of the choices they make when entering tertiary study. The chief reasons for this, they posit, is that study mode choice impacts on both the learning and the social environments that students will encounter, and it conditions the flexibility that students have to organise other aspects of their lives. Their claim provides support for the premise of this article - that study mode choice is significant and important to analyse - and a backdrop for broader literature on the subject. There are numerous lenses through which these decisions can be analysed. In this project we have categorised influences on enrolment choice into six factors: personal, logistics, teaching and learning, learning support, environment, and advice and marketing.

\section{Personal influences}

Socio-economic indicators and geographic location have also been found to strongly influence student choices (Bornholt, Gientzotis, \& Cooney, 2004). For example, James et al. (1999) found that residence in regional or remote locations can shape students' study pathways. Similarly, there is a broad literature on the role that demographic factors play in influencing the choice of study mode: enrolment trends indicate that women are more likely than men to choose online study as a means to pursue a degree (Price, 2006). Moore and Kearskey (2005) have observed an age affect: distance education students are likely to be older than on-campus learners, while school leavers have been shown to be attracted to face-to-face study (Hagel \& Shaw, 2010).

\section{Logistics influences}

For such students who choose online study, flexibility and convenience have been found to be major influences (Ding \& Boody, 2011; Jaggers, 2014). Braun’s (2008) research with students that had experience with both face-to-face and online study found that the need for flexibility outweighed the perceived benefits of face-to-face learning. For example, the ability to complete coursework off campus was viewed as beneficial by students with families, especially considering $90 \%$ of the online students Braun surveyed were women. This reinforces the findings of other research that found the time demands of on-campus study to be a disincentive, particularly for older students (Mahieu \& Wolming, 2013; Romero \& Usart, 2014) and those with busy lives (Brown, 2012; Kirkwood, 2000).

\section{Teaching and learning influences}

O’Neill and Sai (2014) found in their study of North American psychology students that studying face-toface was not tradable for the convenience of online study with a majority view that on-campus attendance would provide better learning outcomes for them. This supports other studies in which on-campus students believe that face-to-face instruction is integral to learning (Hagel \& Shaw, 2010), and that engagement with their instructors is crucial to this dynamic (Jaggers, 2014; Paechter \& Maier, 2010). Online study, for its part, can also be appealing because of its structure, immediacy and its capacity to support self-regulated learning (Paechter \& Maier, 2010). Perceptions of educational outcomes are also tied to the reputation of both instructors and institutions, which have been shown to be a motivating factor for enrolment in courses either on-campus or online (Aslanian \& Clintefelder, 2013).

\section{Learning support influences}

Targeted student support services can have a positive impact on motivation to study, academic achievement (Wibrowski, Matthews, \& Kitsantas, 2016) and retention (Bunn, 2004). More broadly, student support services have been found to have a direct relationship to the ways in which students experience university (Dominguez-Whitehead, 2017; Lee, Srinivasan, Trail, Lewis, \& Lopez, 2011). This is the case for both oncampus and distance education students, with support seen, particularly, as critical for retention rates amongst off-campus students (Bunn, 2004). Despite this, there has been little research on how the presence of support services impact on student enrolment choice. Our study draws on scholarship about the importance of support services to ask students how they impact on decisions about enrolment. 


\section{Environment influences}

Although one UK study found that a poor physical infrastructure was a deterrent to enrolment (Winter \& Chapleo, 2017), and other studies have linked campus design to student retention (Hajrasouliha \& Ewing, 2016), the majority of research into environmental influences on enrolment choice have been concerned with the social dimensions of campus life. Jaggers' (2014) study of community college students, for example, found that connection with fellow students and teachers was a motivator for students to enrol in face-to-face classes. This supports other studies that have found sociability to be an indicator of student satisfaction (Reio \& Crim, 2013) and a motivator to enrol in on-campus study (Harrington \& Loffredo, 2010; Paechter \& Maier, 2010). For students in one Australian study, this meant a willingness to pay more and attend a less favourable institution in order to derive these benefits (Hagel \& Shaw, 2010).

\section{Advice and marketing influences}

Hemsley-Brown and Oplatka (2016) argue that from a marketing perspective, universities, like other service organisations, need to focus on consumer recruitment and satisfaction to manage "profitable customer relationships" (p. 2). As such, advice and marketing are important influences on student enrolment choices, but it is important that resources in this area are targeted to student need. If, for example, students' decisions about what course they take at university are based on employment and career prospects as Maringe (2006) found, then a university's marketing needs to shape promotions and guidance to this need. This article provides evidence for such a focus and expands on the extant scholarship on student enrolment choice outlined above.

\section{Research questions and hypotheses}

This student survey study was designed to investigate factors that influence student study mode choice. It was run in the Faculty of Arts at an institution that delivers subjects across three modes of delivery: oncampus (face-to-face learning that is sometimes blended with online elements), distance (off-campus learning that is largely online, but which may include on-campus elements), and open and online (completely online learning that is offered through Open Universities Australia (OUA)). It is guided by the hypothesis that there are differences in the importance of factors (personal, logistics, teaching and learning, support for learning, environment, and advice and marketing) among students who enrol in different modes of study.

\section{Method}

\section{Setting and context}

The institution in which the survey was run has offered multiple modes of delivery for more than 10 years. In recent years it has been a requirement that subjects included a website for all modes of delivery, including face-to-face instruction. Most units in the Faculty of Arts are offered in both internal and external enrolment mode for students, with a substantial subset of these also being offered through OUA - an umbrella group that provides students with access to a range of units and qualifications taught by Australian universities. The cross-mode delivery of Faculty of Arts subjects provides an ideal opportunity to test student study mode choice. All on-campus students who chose to engage in face-to-face learning also had the opportunity to enrol in distance or open and online study of the same subjects. Their enrolment decision was thus not influenced by content or subject restrictions because the same options were available to them through any mode of study. Those who chose to enrol in distance or open and online subjects had the same choice framework. Similarly, then, their decisions about enrolment were not influenced by subject availability but by other factors. To ensure that it was these factors that we measured, the survey sample was drawn from subjects that were being simultaneously offered in all three modes. A total of 744 students responded to the survey.

\section{Instrument}

The survey consisted of the following sections: (a) Enrolment profile, (b) Motivation to study, (c) Factors influencing initial choice of study, (d) Demographics. The subscale for motivation to study drew on a diverse range of previous scholarship and an existing OUA survey. One of the authors of this article helped 
to develop the OUA survey. Its questions provided a guide to the concerns students had when enrolling in OUA study and the issues that were important to them when making choices at this time. This, along with extant published scholarship on motivations for enrolment choices and online participation (Allen \& Seaman, 2011; Aslanian \& Clintefelder, 2013; Braun, 2008; Bunn, 2004; Hagel \& Shaw, 2010; Hrastinski \& Jaldemark, 2012; Romero \& Usart, 2014) helped us to conceptualise influences on enrolment. From here we drafted questions and sought feedback from learning and teaching professional staff and administrators at our institution, before settling on the final question bank for the survey. The items were answered on a five-point Likert scale (5 = extremely important; 4 = very important; 3 = neither important nor unimportant; 2 = very unimportant; $1=$ not at all important). Table 2 shows example items of the different subscales. Subscales have been successfully tested for reliability with Cronbach's alpha $.681 \leq r \leq .869$. The survey was implemented on the Qualtrics platform (http://www.qualtrics.com). It took approximately 15 minutes to complete the survey.

\section{Data collection and analysis}

Based on enrolment lists from the relevant teaching units, participants were invited to complete the survey using the Qualtrics platform bulk email function. All data stored on the Qualtrics platform was anonymised, exported, and analysed using SPSS V22.0. Six factors (personal, logistics, teaching and learning, learning support, environment, advice and marketing) were computed by the average of items comprising the factor. Initial data checks showed that the distributions of ratings and scores satisfied the assumptions underlying the analysis procedures. All effects were assessed at the .05 level.

\section{Results}

\section{Differences in importance of factors}

Table 1 provides means, standard deviations, F-tests results, and effect sizes of the importance of factors that influenced decisions students made for the three enrolment modes (on-campus, distance, open and online) when commencing study.

Table 1

Means (standard deviations in parentheses), F-test results, and effect sizes for importance of factors for the three enrolment modes (on-campus, distance, open and online), $N=744$

\begin{tabular}{llllll}
\hline \multirow{2}{*}{ Factor } & \multicolumn{5}{c}{ Enrolment mode } \\
On-campus & Distance & Open/Online & $\boldsymbol{F ( 2 , 7 4 3 )}$ & Eta2 \\
\hline Personal & $3.07(.58)$ & $2.89(.73)$ & $2.88(.78)$ & $6.365^{* *}$ & 0.017 \\
Logistics & $3.32(.77)$ & $3.52(.71)$ & $3.68(.59)$ & $13.023^{* * *}$ & 0.034 \\
Teaching and learning & $3.42(.90)$ & $3.73(.77)$ & $3.81(.70)$ & $12.888^{* * *}$ & 0.034 \\
Learning support & $3.31(.85)$ & $3.23(.94)$ & $3.26(.94)$ & 0.341 & 0.001 \\
Environment & $3.28(.82)$ & $2.54(1.14)$ & $1.91(.94)$ & $126.889^{* * *}$ & 0.255 \\
Advice and marketing & $3.27(.77)$ & $2.77(1.06)$ & $2.74(1.109)$ & $26.261^{* * *}$ & 0.066 \\
\hline
\end{tabular}

Note. ${ }^{*} p<.05 ; * * p<.01 ; * * * p<.001$

For personal factor, Tukey-HSD post-hoc comparisons between the enrolment modes indicated that oncampus students $(M=3.07,95 \%$ CI [3.03, 3.12]) rated significantly higher than open and online students $(M=2.88,95 \%$ CI [2.73, 3.02]), $p<.01$. All other pair-wise comparisons between cohorts were not statistically significant.

For logistics factor, Tukey-HSD post-hoc comparisons between the enrolment modes indicated that open and online students $(M=3.68,95 \%$ CI $[3.57,3.79])$ rated significantly higher than on-campus students ( $M$ $=3.32,95 \%$ CI $[3.25,3.38]), p<.01$. All other pair-wise comparisons between cohorts were not statistically significant.

For teaching and learning factor, Tukey-HSD post-hoc comparisons between the enrolment modes indicated that distance students $(M=3.73,95 \%$ CI $[3.55,3.91])$ rated significantly higher than on-campus students $(M=3.42,95 \%$ CI [3.34, 3.49]), $p<.01$. Additionally, open and online students $(M=3.81,95 \%$ CI $[3.68,3.94])$ rated significantly higher than on-campus students $(M=3.42,95 \%$ CI $[3.34,3.40]), p<$ 
.001. The comparison between distance students and open and online students was not statistically significant.

For environment factor, Tukey-HSD post-hoc comparisons between the enrolment modes indicated that on-campus students $(M=3.28,95 \% \mathrm{CI}[3.21,3.35])$ rated significantly higher than distance students $(M=$ 2.54, 95\% CI [2.28, 2.81]), $p<.001$. Additionally, on-campus students $(M=3.28,95 \%$ CI $[3.21,3.35])$ rated significantly higher than open and online students $(M=1.91,95 \%$ CI $[1.74,2.09]), p<.001$. Last, distance students $(M=2.54,95 \% \mathrm{CI}[2.28,2.81])$ rated significantly higher than open and online students $(M=1.91,95 \%$ CI $[1.74,2.09]), p<.001$.

For advice and marketing factor, Tukey-HSD post-hoc comparisons between the enrolment modes indicated that on-campus students $(M=3.27,95 \% \mathrm{CI}[3.21,3.34])$ rated significantly higher than distance students ( $M=2.77,95 \%$ CI [2.52, 3.01]), $p<.001$. Additionally, on-campus students $(M=3.27,95 \%$ CI $[3.21,3.34])$ rated significantly higher than open and online students ( $M=2.74,95 \%$ CI $[2.54,2.94]), p<$ .001. The comparison between distance students and open and online students was not statistically significant.

\section{Post-hoc item level analysis}

In order to gain more insights into the importance of factors influencing the decisions of students for enrolling in a specific study mode, a post-hoc item level analysis was conducted. Table 2 provides means and standard deviations of the importance of single items that influenced decisions students made for the three enrolment modes when commencing their study.

Table 2

Post-hoc item level analysis for the three enrolment modes (on-campus, distance, open and online) including means (standard deviations in parentheses)

\begin{tabular}{|c|c|c|c|c|}
\hline \multirow[b]{2}{*}{ Factor } & \multirow[b]{2}{*}{ Short item description } & \multicolumn{3}{|c|}{ Enrolment mode } \\
\hline & & On-campus & Distance & Open/Online \\
\hline \multirow[t]{5}{*}{ Personal } & Personal & $3.68(1.31)$ & $4.10(1.12)$ & $4.30(1.01)$ \\
\hline & Cultural/religious orientation & $2.67(1.20)$ & $1.95(1.11)$ & $1.92(1.11)$ \\
\hline & Specific/special learning needs & $2.90(1.13)$ & $2.74(1.34)$ & 2.58 (1.39) \\
\hline & Confidence in academic ability & 3.50 (1.09) & $3.47(1.25)$ & $3.48(1.26)$ \\
\hline & Prior experience with institution & $2.61(1.20)$ & $2.19(1.25)$ & $2.12(1.20)$ \\
\hline \multirow[t]{8}{*}{ Logistics } & Cost per unit & $2.92(.95)$ & $2.89(1.03)$ & $3.35(1.16)$ \\
\hline & Distance from campus & $3.41(1.04)$ & $3.60(1.23)$ & $2.98(1.52)$ \\
\hline & Ease of access to campus & $3.51(1.08)$ & $3.47(1.26)$ & $2.37(1.36)$ \\
\hline & Flexibility in studying at own pace & $3.38(1.11)$ & 3.79 (1.09) & $4.25(.86)$ \\
\hline & $\begin{array}{l}\text { Flexibility in studying at time of } \\
\text { choosing }\end{array}$ & $3.43(1.16)$ & $4.04(1.05)$ & $4.53(.75)$ \\
\hline & $\begin{array}{l}\text { Flexibility in managing work-life- } \\
\text { study balance }\end{array}$ & $3.48(1.22)$ & $4.06(1.06)$ & 4.45 (.93) \\
\hline & $\begin{array}{l}\text { Flexibility in studying at other } \\
\text { universities }\end{array}$ & 2.75 (1.07) & $2.43(1.11)$ & $3.47(1.15)$ \\
\hline & $\begin{array}{l}\text { Range of units available to choose } \\
\text { from }\end{array}$ & $3.63(1.24)$ & 3.88 (.93) & $4.07(.92)$ \\
\hline \multirow{6}{*}{$\begin{array}{l}\text { Teaching and } \\
\text { learning }\end{array}$} & Extent of online content & $3.24(1.00)$ & $3.89(1.14)$ & $4.22(.93)$ \\
\hline & $\begin{array}{l}\text { Work collaboratively with other } \\
\text { students }\end{array}$ & $3.21(.92)$ & $2.79(1.12)$ & 2.76 (1.09) \\
\hline & Access to study resources & $3.55(1.20)$ & $4.02(1.01)$ & $4.25(.91)$ \\
\hline & Expected workload & $3.43(1.06)$ & $3.87(.95)$ & $3.96(.94)$ \\
\hline & Engagement with academic staff & $3.44(1.04)$ & $3.81(.95)$ & $3.76(.95)$ \\
\hline & Reputation of high quality teaching & $3.62(1.21)$ & $3.99(1.05)$ & $3.92(.94)$ \\
\hline
\end{tabular}




\begin{tabular}{lllll}
\hline Learning & Access to learning support services & $3.19(.97)$ & $2.80(1.26)$ & $2.94(1.22)$ \\
support & Access to IT support services & $3.23(.96)$ & $3.24(1.11)$ & $3.21(1.09)$ \\
& $\begin{array}{l}\text { Access to course and careers } \\
\text { advice }\end{array}$ & $3.44(1.02)$ & $3.29(1.17)$ & $3.11(1.19)$ \\
& Ease of administration & $3.37(1.02)$ & $3.61(1.04)$ & $3.78(.97)$ \\
\hline \multirow{2}{*}{ Environment } & Access to personal support & $3.13(1.00)$ & $2.59(1.40)$ & $2.18(1.25)$ \\
& Access to campus facilities & $3.23(.92)$ & $2.41(1.24)$ & $1.66(.98)$ \\
& Meeting and socialising with other & $3.47(1.02)$ & $2.64(1.30)$ & $1.91(1.06)$ \\
& students & & & \\
\hline Advice and & Experience of other students & $3.38(.95)$ & $2.85(1.30)$ & $2.55(1.26)$ \\
marketing & Advertising, website, social media & $3.17(.88)$ & $2.78(1.21)$ & $2.76(1.19)$ \\
& Advice from student advisors & $3.27(.95)$ & $2.68(1.26)$ & $2.91(1.32)$ \\
\hline
\end{tabular}

Note. ${ }^{*} p<.05 ; * * p<.01 ; * * * p<.001$

\section{Discussion}

Figure 1 summarises the findings for the importance of the six factors for each study mode. It shows that all cohorts ascribed high importance to the logistics factor and the teaching and learning factor. This correlates with a range of identified influences on student decision-making, including perceptions of quality teaching (Aslanian \& Clinefelter, 2013), flexibility (Braun, 2008; Clayton et al., 2010), ease of access (Hagel \& Shaw, 2010; Young \& Norgard, 2006), student schedules (Romero \& Usart, 2014) and workload expectations (Brown, 2012; Jaggers, 2014).

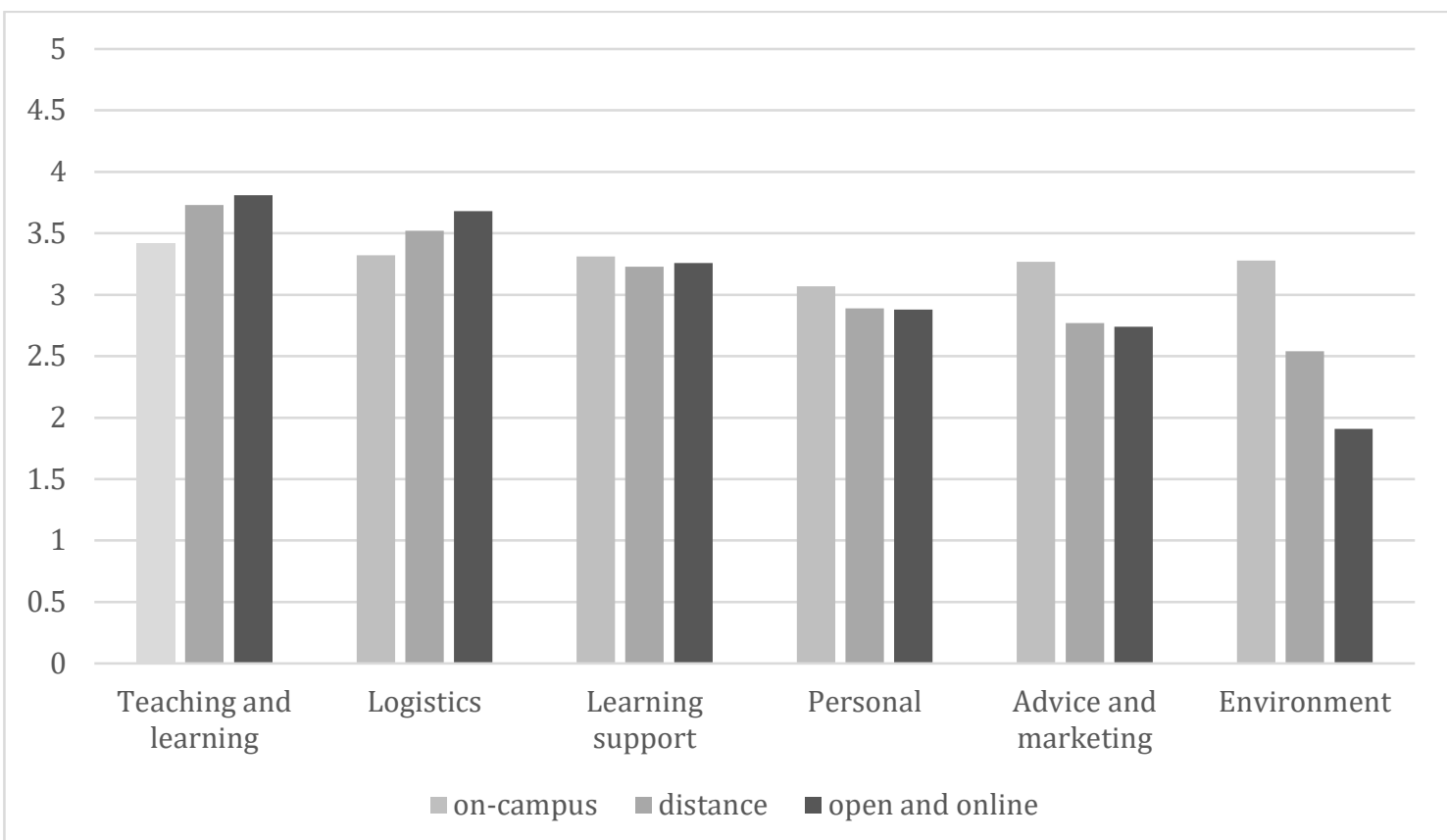

Figure 1. Order of importance of factors for initial enrolment for three modes (on-campus, distance, open and online)

\section{Teaching and learning}

As Table 2 shows, the teaching and learning factor was composed of items that measured delivery and resourcing rather than content. Policy at the university is for the latter to be equivalent across modes, but anecdotal evidence, as well as broader scholarship, suggests that the way in which it is delivered can be problematic and can impact on the experience of students, as well as their learning outcomes (Song, Singleton, Hill, \& Koh, 2004). This is emphasised by the fact that all cohorts ranked teaching and learning as the most important factor, with the off-campus cohorts ranking it significantly higher than the on-campus 
cohort. This demonstrates the high expectations that online students hold and the need, in an increasingly competitive marketplace (de Zilwa, 2010), for universities to meet these expectations.

When examining the six items comprising this factor (Table 2), a number of trends emerged:

- There is less variation in the importance of items for on-campus students compared to the open and online and distance cohorts.

- Cohorts from all three modes rate access to study materials and resources highly, although this is particularly high amongst the distance and open and online cohorts.

- Cohorts from all three modes rated group collaborative work as the least important influence on their choice of study mode.

The open and online and distance cohorts understandably ranked the extent to which teaching is conducted online higher (mean importance of 4.22 and 3.89 respectively) than the on-campus cohort as an influence on enrolment, although the latter's mean importance of 3.24 on this item reflects a growing expectation amongst students that technology will be integral to their higher education learning experience (Dahlstrom \& Bichsel, 2014; Gosper, Malfroy, \& McKenzie, 2013; Gosper, McKenzie, Pizzica, Malfroy, \& AshfordRowe, 2014). Our study suggests a degree of ambivalence amongst off-campus students about opportunities to engage in collaborative learning, with the on-campus cohort recording significantly higher mean importance on this item (3.21) than the distance (2.79) and open and online cohorts (2.76). Scholarship in this area suggests that while educators recognise the value of online collaborative projects (McConnell, 1994), the success of implementation is varied and dependent on the ways in which it is integrated with assessment (Macdonald, 2003). When making choices about enrolment, students appear cognisant of these difficulties.

In terms of pedagogical items, the online and distance cohorts gave significantly higher importance to access to study materials and resources, engagement with academic staff, and reputation of high quality teaching when considering their mode of enrolment. These indicate some of the key requirements that offcampus learners identify as crucial to their learning experience: the high importance placed on quality teaching and engagement with academic staff is congruent with a range of studies that have shown a close link between online students' perceptions of staff engagement and course satisfaction as well as learning outcomes (Baker, 2004; Lee et al., 2011). The need for easy and transparent access to support (Lee et al., 2011), instructional clarity (Lim, Morris, \& Kupritz, 2007) and learning materials (Bunn, 2004) is also well documented. None of these are unimportant to on-campus students, but physical access to services, academics and fellow students may offer support networks that mitigate shortfalls in their delivery when compared with the off-campus experience. Again, students appear to be weighing these issues when making enrolment choices.

\section{Logistics}

All cohorts ranked logistics as the second highest factor in terms of mean importance. There were differences, though, between cohorts: for both off-campus cohorts, logistics was significantly more important than it was for the on-campus cohort. That logistics ranked so highly across the whole sample is indicative of the nature of study, work, and life balances that face students studying today (Baron \& Corbin, 2012). Even in 2009, it was estimated that more than $60 \%$ of Australian students studying full-time were in paid employment for almost 2 days a week. Almost $70 \%$ of these were forced to do so to meet everyday needs (James, Krause, \& Jennings, 2010). Research has found that $75 \%$ of tertiary students aged 20-25 are engaged in employment, with $80 \%$ working more than 8 hours a week, and 22\% working in excess of 24 hours a week (Horin, 2011). An analysis of the contributing items to the logistics factor shows that both the open and online and distance cohorts registered significantly higher mean importance for most items related to flexibility (Table 2). This aligns with a broad range of literature demonstrating that distance and online students make choices about study mode to maximise their time and place flexibility (Clayton, Blumberg, \& Auld, 2010; Hagel \& Shaw, 2010).

The high importance that all students ascribed to the logistics factor should be noted by program directors, support staff and administrators. Broader economic issues, such as rental affordability and rising living costs, will continue to influence the choices that students make about employment during study. Between 2007 and 2017, housing rentals in Australia rose by 48\%, compared with an increase of 31\% for the 
minimum wage (Jericho, 2017). It is thus more expensive to rent now, particularly for low-income earners such as students, than it has been in the past. This will vary depending on geographic location - Sydney and Melbourne, for example, have seen extraordinary increases in property prices over this time period. Whilst many students make adjustments such as choosing to live at home for longer, more research on the impact of macroeconomic forces on student study patterns is required. At the least, cognisance of these issues and efforts to provide flexibility through online and blended offerings should be intrinsic to program planning if the needs of students are to be adequately addressed.

\section{Learning and support}

The learning and support factor was ranked third in mean importance in all cohorts with no significant difference in importance between cohorts. The relatively high mean importance of the factor across all cohorts adds evidence that "support for student learning is a key element in optimizing student learning experiences" (Lee et al., 2011, p. 158; Wibrowski et al., 2016). Our data indicates that this is a view shared by students and that perceptions about support services influences their decision-making at the point of enrolment. From an institutional point of view, this highlights the need to develop resilient support services (Dominguez-Whitehead, 2017; Stephens et al., 2014), as well as the importance of providing early clarity in communicating their availability to students and transparent pathways towards their access (Chenoweth, Ushida, \& Murday, 2006; Lee et al., 2011).

Although earlier studies have found that online students had a particular need for technological support (Chenoweth et al., 2006; Levy, 2003), our study found the mean importance of the item access to IT services and support to be virtually equivalent across cohorts. This is reflective of the rapid expansion of learning technologies in higher education, including the widespread application of blended learning pedagogies (Dahlstrom \& Bichsel, 2014; Wheelan, 2016). The sample population in this survey, for example, experience a high level of information technology integration in all delivery modes. Courses run through the faculty are required to have a website within the university's learning management system, while the recording of live lectures, which are subsequently made available online, is common. This highlights the importance of cohesive technological support structures that are readily accessible to all students across all enrolment modes (Lee, 2010). The need for this is further supported by the work of Kennedy, Judd, Churchward, Gray, and Krause (2008), which shows there can be a "digital divide" between students within single cohorts that can be masked by generalisations about “digital natives” (Prensky, 2001, p. 1).

In our study, on-campus students gave more importance to the item access to services to support learning (mean of 3.19) than either the distance (mean of 2.8) or open and online cohorts (mean of 2.94). This adds some weight to previous studies, which have found that off-campus students prefer independence (Braun, 2008), but may also reflect lower expectations of institutional support amongst students who do not physically visit the campus. This should not be confused with instructional support within courses - as item-level analysis of the teaching and learning factor shows above, engagement with academic staff remains very important for off-campus students in this study.

\section{Personal}

The personal factor, which measured the influence on enrolment of cultural and religious orientation, levels of confidence and experience with study, as well as specific or special learning needs, received the lowest mean ranking for the on-campus cohort. Distance and open and online students gave it a similar ranking, but for these cohorts, the personal factor was still more important than the environment and advice and marketing factors. When looking at the item level, distance and open and online students gave more importance (mean of 4.1 and 4.3 respectively) than on-campus students (mean of 3.68) to the personal item within the personal factor. This item was intended as a measure to capture the personal circumstances that previous studies have found influential on study mode choice, and which in many cases drives off-campus students' needs for flexibility discussed above (Bornholt et al., 2004; Clayton et al., 2010; Hagel \& Shaw, 2010; Price, 2006).

On-campus students ranked the religious and cultural item as a stronger influence on enrolment mode choice (mean of 2.67) than distance and open and online students (mean of 1.95 and 1.92 respectively). Investment in the cultural life of universities provides the opportunity to foster cross-cultural awareness and social cohesion (Andersson, Sadgrove, \& Valentine, 2012; Volet \& Ang, 1998); helps prepare students 
for life in a multicultural, pluralist society; can assist with social adjustment for some student bodies (Myles \& Cheng, 2003); and produces higher retention rates through improved social integration (Gerdes \& Mallinckrodt, 1994). While not operating as a major driver of study mode choice, the mean importance accorded to religious and cultural factors by on-campus students does indicate that campus activities, clubs, cultural infrastructure and support services are viewed as a part of the social fabric of the university environment. The lower mean importance for this item amongst off-campus students suggests a space for stronger investment in the creation of online communities to support the social dimensions of their learning experience (Duffy, 2013) and the promotion of such infrastructure prior to enrolment to inform student decision-making.

\section{Environment}

Braxton, Hirschy, and McClendon (2004) noted that student characteristics, including work-life patterns and study commutes, affect their adjustment to campus environments. They suggested that commuting students in the United States spent comparatively little time on campus and were largely focused on attending classes and meeting degree requirements. In Australia today this is arguably even more the case: Internet and communication technologies have long been seen as a disruptive and innovative force in higher education (Andrews \& Tynan, 2012; Archer, Garrison, \& Anderson, 1999; Garrison \& Kanuka, 2004), and have been embraced to a considerable degree by Australian institutions. This has resulted in a reconceptualisation of the ways in which students engage with each other and the physical campus. Prerecorded lectures, for example, are available for most courses that students in this study's sample are enrolled in. The additional flexibility that this provides on-campus students expands the parameters available to students as they construct study patterns, complicating notions of typical study schedules determined by enrolment mode (Woo et al., 2008). Nonetheless, in this study there remains a significant difference in the mean importance attached to the environment factor by the on-campus cohort on one side and the distance and open and online cohort on the other. This is explained by the items comprising the environment factor, two out of three of which are characterised by face-to-face or on-campus activity (see Table 2). The comparatively high mean importance of the environmental factor for the on-campus cohort is a reminder to administrators, amidst the influx of technology, of the need to provide an engaging and supportive study environment for students enrolled in face-to-face instruction (Hajrasouliha \& Ewing, 2016; Winter \& Chapleo, 2017).

The greater congruence between the two off-campus cohorts can be explained by similarities in delivery: distance students in this survey conduct the vast majority of their study online, with very little provision made for face-to-face sessions on campus. The main difference between distance and open and online students is that the former tend to be younger and are more likely to live closer to the university. In this regard, work or other commitments are likely to be stronger drivers of their enrolment mode choice than geographic location. Distance students also share privileges of on-campus students in terms of access to support services, the library and campus facilities. This closer affiliation with the campus explains the significant difference in mean importance for the environment factor amongst distance students when compared with open and online students.

\section{Advice and marketing}

For the two off-campus cohorts, advice and marketing was ranked as the second lowest factor in terms of mean importance. There was a significant difference between these cohorts and the on-campus cohort. This suggests the former cohorts are more self-determined in their approach to university study. This may in part be a factor of experience and maturity, as off-campus students have an older average age than their oncampus peers. It may also result from the strength of other influences such as life stage and demographic factors (Mahieu \& Wolming, 2013; Moore \& Kearsley, 2005; Romero \& Usart, 2014), which potentially operate as guiding frameworks for decision-making that exert more influence than university marketers and advisers. It is also possible that the latter are less effective at reaching off-campus students than those who are physically accessible on campus. Although further research is required to make a determination about this dynamic, understanding higher education consumer choice has never been more important in what is an increasingly competitive landscape (Hemsley-Brown \& Oplatka, 2016). 


\section{Limitations and further research}

While this study offers a number of insights into student enrolment mode choice, it also contains limitations. As a study of humanities students the results are informative of decisions made in other disciplines but not directly transferable. Students enrolled in a science subject online, for example, may well place a higher importance on the learning and support factor if they feel a need for support and clarification of complex technical know-how. As an Australian study, similarly, this research offers pointers to student behaviour in other markets but conclusions about such behaviour should be treated cautiously. In both these cases, however, we would argue that the factors explored here offer a useful guide to the issues of which academic administrators should be cognisant when designing programs of study and support networks for students.

Further research across a broader range of disciplines, institutions and markets would thus offer useful additional evidence that would assist in managerial decision-making about student services and program delivery. Follow-up qualitative studies would also provide a more complete understanding of the issues students face when enrolling in higher education. Pre-emptive research along these lines will become more important as the issue of retention rates continues to gain traction at an institutional and political level. Finally, this research has surveyed choices around enrolment modes, not satisfaction with the delivery of education in these modes. As blended and online learning becomes ever more prevalent in the higher education landscape, quality assurance and systems to support it will continue to grow in importance. Measuring the effectiveness of learning technology implementation across enrolment modes, and student perceptions of it, are examples of the kind of research that will be required to inform administrative decision-making in this time of change.

\section{Conclusion}

This paper has reported on findings examining the factors influencing students' initial decisions about study modes, which provide useful insights that can be used by universities to attract, support and retain students in a competitive environment. The findings indicate that, in comparison with the distance and open and online cohorts, there was less volatility in the mean responses across factors for the on-campus cohort. The range for the latter was 3.07 to 3.42, compared with 2.54 to 3.73 for distance students and 1.91 to 3.81 for open and online students (Table 1). This suggests a need to tailor delivery, pedagogical approaches, support structures, and marketing in ways that resonate and enhance the experience of different cohorts. The only factor that did not register a significant difference between cohorts was learning support. There were, though, differences between cohorts at the item level of this factor that provide information for the ways in which university administrators can best cater to student needs in this space.

For all cohorts, the teaching and learning factor was ranked most important. Both the distance and open and online cohorts rated it significantly higher than the on-campus cohort. At the item level, these latter two cohorts gave a significantly higher mean importance than on-campus students to items including engagement with academic staff, access to study materials and resources, and reputation of high quality teaching. These results emphasise the importance of academics' engagement with off-campus students and the necessity of adequately resourcing off-campus modes of delivery. With little face-to-face contact, and limited physical access to campus facilities and support structures, these students recognise and value contact with lecturers and ready access to study materials. All cohorts ranked the logistics factor second highest in mean importance, but again there was a significant difference between the off-campus cohorts and the on-campus cohort. This supports a wide range of literature on the appeal of flexible study options amongst students pursuing distance and online learning.

These findings - as well as the significant differences detailed above at both the factor and item level between student cohorts in different enrolment modes - demonstrate the many influences on study mode choices. University administrators, as well as learning and teaching support staff and academics should be cognisant of these differences and aware of the ways in which support structures and pedagogical approaches can be aligned with the variable needs of students enrolled in all modes of delivery through which they offer courses. This can enhance the quality and focus of course delivery and may also improve student satisfaction levels and reduce attrition rates. This has both economic and pedagogical value: the former because quality is a differentiating factor in an increasingly competitive market place; the latter because a poor fit in learning style can reduce student satisfaction and increase attrition rates (Harrington \& Loffredo, 2010). Research into student needs and expectations - particularly as technologies, methods 
of instruction and delivery platforms are changing so rapidly - should thus become a central component of information gathering for universities (Hemsley-Brown \& Oplatka, 2016), which should use it to inform the development of teaching practice, support services and learning delivery.

\section{References}

Allen, I. E., \& Seaman, J. (2011). Going the distance: Online education in the United States (Research Report No. 9). Oakland, CA: Babson Survey Research Group \& Quahog Research Group, LLC. Retrieved from http://www.onlinelearningsurvey.com/reports/goingthedistance.pdf

Andersson, J., Sadgrove, J., \& Valentine, G, (2012). Consuming campus: Geographies of encounter at a British university. Social \& Cultural Geography, 13(5), 501-515. https://doi.org/10.1080/14649365.2012.700725

Andrews, T., \& Tynan, B. (2012). Distance learners: Connected, mobile and resourceful individuals. Australasian Journal of Educational Technology, 28(4), 565-579. https://doi.org/10.14742/ajet.828

Archer, W., Garrison, D. R., \& Anderson, T. (1999). Adopting disruptive technologies in traditional universities: Continuing education as an incubator for innovation. Canadian Journal of University Continuing Education, 25(1), 13-30. Retrieved from https://ejournals.library.ualberta.ca/index.php/cjuce-rcepu/article/view/20212/15613

Aslanian, C. B., \& Clintefelder, D. L. (2013). Online college students 2013: Comprehensive data on demands and preferences. Louisville, KY: The Learning House, Inc.

Baker, J. D. (2004). An investigation of relationships among instructor immediacy and affective and cognitive learning in the online classroom. The Internet and Higher Education, 7(1), 1-13. https://doi.org/10.1016/j.iheduc.2003.11.006

Baron, P., \& Corbin, L. (2012). Student engagement: Rhetoric and reality. Higher Education Research \& Development, 31(6), 759-772. https://doi.org/10.1080/07294360.2012.655711

Bates, A. W. (2005). Technology, e-learning and distance education. London: Routledge.

Bornholt, L., Gientzotis, J., \& Cooney, G. (2004). Understanding choice behaviours: Pathways from school to university with changing aspirations and opportunities. Social Psychology of Education, 7(2), 211-228. https://doi.org/10.1023/B:SPOE.0000018560.99580.2a

Bradley, D. (2008). Review of Australian higher education: Final report. Canberra: Department of Education, Employment and Workplace Relations. Retrieved from http://www.innovation.gov.au/HigherEducation/Documents/Review/PDF/Higher Education Review_one document_02.pdf

Braun, T. (2008). Making a choice: The perceptions and attitudes of online graduate students. Journal of Technology and Teacher Education, 16(1), 63-92. Retrieved from https://www.learntechlib.org/p/21874/

Braxton, J., Hirschy, A. S., \& McClendon, S. A. (2004). Understanding and reducing college student departure: ASHE-ERIC Higher Education Report (Vol. 30, No. 3). Hoboken, NJ: Jossey-Bass

Brown, J. (2012). Online learning: A comparison of web-based and land-based courses. Quarterly Review of Distance Education, 13(1), 39-42. Retrieved from http://www.infoagepub.com/qrdeissue.html? $\mathrm{i}=\mathrm{p} 54 \mathrm{c} 3 \mathrm{c} 5059 \mathrm{aa}$ c

Bunn, J. (2004). Student persistence in a LIS distance education program. Australian Academic Research Libraries, 35(3), 253-270. https://doi.org/10.1080/00048623.2004.10755275

Chenoweth, N. A., Ushida, E., \& Murday, K. (2006). Student learning in hybrid French and Spanish courses: An overview of language online. CALICO Journal, 24(1), 115-145. Retrieved from https://calico.org/html/article_96.pdf

Clayton, K., Blumberg, F., \& Auld, D. P. (2010). The relationship between motivation, learning strategies and choice of environment whether traditional or including an online component. British Journal of Educational Technology, 41(3), 349-364. https://doi.org/10.1111/j.1467-8535.2009.00993.x

Currie, J. (2002, April). Australian universities as enterprise universities: Transformed players on a global stage. Paper presented at the IAU 2002 International Conference, Laval University, Quebec, Canada. Retrieved from http://researchrepository.murdoch.edu.au/6607/1/Australian_universities_as_enterprise.pdf

Dahlstrom, E., \& Bichsel, J. (2014). ECAR study of undergraduate students and information technology, 2014. Louisville, CO: ECAR. Retrieved from https://library.educause.edu/ /media/files/library/2014/10/ers1406-pdf.pdf

de Zilwa, D. (2010). Academic units in a complex, changing world: Adaptation and resistance. Heidelberg: Springer. 
Ding, H., \& Boody, R.M. (2001). Reasons why students attend Open University in China. Asian Journal of Distance Education, 9(2), 40-52. Retrieved from http://www.asianjde.org/2011v9.2.Ding.pdf

Dobozy, E., \& Ifenthaler, D. (2014). Initial teacher education by open and distance modes: A snapshot of e-competency experiences in Australia. eLearning Papers, 38, 57-67. Retrieved from https://www.openeducationeuropa.eu/sites/default/files/legacy_files/asset/Digital Literacies and eCompetence_From-field 38_3_0.pdf

Dominguez-Whitehead, Y. (2017). Non-academic support services and university student experiences: Adopting an organizational theory perspective. Studies in Higher Education, 1-15. https://doi.org/10.1080/03075079.2017.1287168

Duffy, K. (2013, July). Supporting part time students through transition from further education to higher education: Fostering conditions for a caring community. Paper presented at Edulearn13, International Conference on Education and New Learning Technologies, Barcelona, Spain. Retrieved from http://sure.sunderland.ac.uk/4423/

Garrison, R., \& Kanuka, H. (2004). Blended learning: Uncovering its transformative potential in higher education. The Internet and Higher Education, 7(2), 95-105. https://doi.org/10.1016/j.iheduc.2004.02.001

Gerdes, H., \& Mallinckrodt, B. (1994). Emotional, social, and academic adjustment of college students: a longitudinal study of retention. Journal of Counseling \& Development, 72(3), 281-288. https://doi.org/10.1002/j.1556-6676.1994.tb00935.x

Gosper, M., Malfroy, J., \& McKenzie, J. (2013). Students’ experiences and expectations of technologies: An Australian study designed to inform planning and development decisions. Australasian Journal of Educational Technology, 29(2), 268-282. https://doi.org/10.1234/ajet.v29i2.127

Gosper, M., McKenzie, J., Pizzica, J., Malfroy, J., \& Ashford-Rowe, K. (2014). Student use of technologies for learning - what has changed since 2010? In B. Hegarty, J. McDonald, \& S-K. Loke (Eds.), Rhetoric and reality: Critical perspectives on educational technology. Proceedings ascilite Dunedin 2014 (pp. 209-301). Retrieved from http://ascilite.org/conferences/dunedin2014/files/fullpapers/211-Bailey.pdf

Hagel, P., \& Shaw, R. (2010). How important is study mode in student university choice? Higher Education Quarterly, 64(2), 161-182. https://doi.org/10.1111/j.1468-2273.2009.00435.x

Hajrasouliha, A. H., \& Ewing, R. (2016). Campus does matter: The relationship of student retention and degree attainment to campus design. Planning for Higher Education Journal, 44(3), 30-45. https://doi.org/10.1111/hea.12078_34

Harrington, R., \& Loffredo, D. A. (2010). MBTI personality type and other factors that relate to preference for online versus face-to-face instruction. Internet and Higher Education, 13(1-2), 89-95. https://doi.org/10.1016/j.iheduc.2009.11.006

Hemsley-Brown, J., \& Oplatka, I. (2016). Higher education consumer choice. London: Palgrave Macmillan.

Horin, A. (2011, January 12). Balance the key for uni students who work. Sydney Morning Herald. Retrieved from http://www.smh.com.au/national/education/balance-the-key-for-uni-students-whowork-20110111-19ms9.html

Hrastinski, S., \& Jaldemark, J. (2012). How and why do students of higher education participate in online seminars? Education and Information Technologies, 17(3), 253-271. https://doi.org/10.1007/s10639011-9155-y

Ifenthaler, D., Bellin-Mularski, N., \& Mah, D.-K. (2015). Internet: Its impact and its potential for learning and instruction. In J. M. Spector (Ed.), The SAGE encyclopedia of educational technology (Vol. 1, pp. 416-422). Thousand Oaks, CA: Sage.

Jaggers, S. S. (2014). Choosing between online and face-to-face courses: Community college student voices. American Journal of Distance Education, 28(1), 27-38. https://doi.org/10.1080/08923647.2014.867697

James, R., Krause, K.-L., \& Jennings, C. (2010). The first-year experience in Australian universities: Findings from 1994 to 2009. Melbourne: Centre for the Study of Higher Education.

James, R., Wyn, J., Baldwin, G., Hepworth, G., McInnes, C., \& Stephanou, A. (1999). Rural and isolated students and their higher education choices: A re-examination of student location, socio-economic background, and educational advantage and disadvantage. Canberra: Australian Government Publishing Service.

Jericho, G. (2017, April 27). Rental affordability at crisis point for low income families. The Guardian. Retrieved from https:/www.theguardian.com/business/grogonomics/2017/apr/27/rental-affordabilityat-crisis-point-for-low-income-families 
Kennedy, G. E., Judd, T. S., Churchward, A., Gray, K., \& Krause, K. L. (2008). First year students’ experiences with technology: Are they really digital natives? Australasian Journal of Educational Technology, 24(1), 108-122. https://doi.org/10.14742/ajet.1233

Kirkwood, A. (2000). Learning at home with information and communication technologies. Distance Education, 21(2), 248-259. https://doi.org/10.1080/0158791000210204

Lee, C. Y. (2015). Changes in self-efficacy and task value in online learning. Distance Education, 36(1), 59-79. https://doi.org/10.1080/01587919.2015.1019967

Lee, J. W. (2010). Online support service quality, online learning acceptance, and student satisfaction. Internet and Higher Education, 13(4), 277-283. https://doi.org/10.1016/j.iheduc.2010.08.002

Lee, S. J., Srinivasan, S., Trail, T., Lewis, D., \& Lopez, S. (2011). Examining the relationship among student perception of support, course satisfaction, and learning outcomes in online learning. Internet and Higher Education, 14(3), 158-163. https://doi.org/10.1016/j.iheduc.2011.04.001

Lefoe, G., \& Albury, R. (2004). Editorial. Educational Media International, 41(2), 181-182. https://doi.org/10.1080/09523980410001678548

Lefoe, G., \& Hedberg, J. (2006). Blending on and off campus: A tale of two cities. In C. Bonk \& C. R. Graham (Eds.), Handbook of blended learning environments: Global perspectives, local designs (pp. 325-337). San Francisco, CA: Pfeiffer.

Levy, S. (2003). Six factors to consider when planning online distance learning programs in higher education. Online Journal of Distance Learning Administration, 6(1). Retrieved from http://www.westga.edu/ distance/ojdla/spring61/levy61.htm

Liaw, S. S., Huang, H. M., \& Chen, G. D. (2007). Surveying instructor and learner attitudes toward elearning. Computers \& Education, 49(4), 1066-1080. https://doi.org/10.1016/j.ijinfomgt.2006.08.002

Lim, D., Morris, M., \& Kupritz, V. (2007). Online vs. blended learning: Differences in instructional outcomes and learner satisfaction. Journal of Asynchronous Learning Networks, 11(2), 27-42. Retrieved from ERIC database. (EJ842695)

Macdonald, J. (2003). Assessing online collaborative learning: process and product. Computers \& Education, 40, 377-391. https://doi.org/10.1016/S0360-1315(02)00168-9

Mahieu, R., \& Wolming, S. (2013). Motives of lifelong learners to choose web-based courses. European Journal of Open, Distance and E-Learning, 16(1), 1-10. Retrieved from http://www.eurodl.org/materials/contrib/2013/Mahieu_Wolming.pdf

Maringe, F. (2006). University and course choice: Implications for positioning, recruitment and marketing. International Journal of Educational Management, 20(6), 466-479. https://doi.org/10.1108/09513540610683711

McConnell, D. (1994). Implementing computer supported co-operative learning. London: Kogan Page.

Moore M. G. (2003) Preface. In M. G. Moore \& W. G. Anderson (Eds.), Handbook of distance education (pp. ix-xii). Mahwah, NJ: Lawrence Erlbaum Associates.

Moore, M. G., \& Kearsley, G. (2005). Distance education: A systems view. Belmont, CA: Wadsworth.

Myles, L., \& Cheng, L. (2003). The social and cultural life of non-native english speaking international graduate students at a Canadian university. Journal of English for Academic Purposes, 2(3), 247-263. https://doi.org/10.1016/S1475-1585(03)00028-6

O'Neill, D. K., \& Sai, T. H. (2014). Why not? Examining college students' reasons for avoiding an online course. Higher Education, 68(1), 1-14. https://doi.org/10.1007/s10734-013-9663-3

Paechter, M., \& Maier, B. (2010). Online or face-to-face? Students’ experiences and preferences in elearning. Internet and Higher Education, 13(4), 292-297. https://doi.org/10.1016/j.iheduc.2010.09.004

Prensky, M. (2001). Digital natives, digital immigrants: Part 1. On the Horizon, 9(5), 1-6. https://doi.org/10.1108/10748120110424816

Price, L. (2006). Gender differences and similarities in online courses: Challenging stereotypical views of women. Journal of Computer Assisted Learning, 22(5), 349-359. https://doi.org/10.1111/j.13652729.2006.00181.X

Reio, T. G., \& Crim, S. J. (2013). Social presence and student satisfaction as predictors of online enrollment intent. American Journal of Distance Education, 27(2), 122-133. https://doi.org/10.1080/08923647.2013.775801

Romero, M., \& Usart, M. (2014). The temporal perspective in higher education learners: Comparisons between online and onsite learning. European Journal of Open, Distance and e-Learning, 17(1), 190209. https://doi.org/10.2478/eurodl-2014-0013 
Song, L., Singleton, E. S., Hill, J. R., \& Koh, M. H. (2004). Improving online learning: Student perceptions of useful and challenging characteristics. The Internet and Higher Education, 7(1), 59-70. https://doi.org/10.1016/j.iheduc.2003.11.003

Stephens, M., Wedaman, D., Freeman, E., Hicks, A., Matthews-DeNatale, G., Wahl, D., \& Spiro, L. (2014). Academic 15: Evaluating library and IT staff responses to disruption and change in higher education. First Monday, 19(5). https://doi.org/10.5210/fm.v19i5.4635

Volet, S. E., \& Ang, G. (1998). Culturally mixed groups on international campuses: An opportunity for inter-cultural learning. Higher Education Research \& Development, 17(1), 5-23. https://doi.org/10.1080/0729436980170101

Wheelan, P. (2016). Flipping student support services to improve outcomes. Change: The Magazine of Higher Learning, 48(6), 36-41. https://doi.org/10.1080/00091383.2016.1247581

Wibrowski, C. R., Matthews, W. K., \& Kitsantas, A. (2016). The role of a skills learning support program on first-generation college students' self-regulation, motivation, and academic achievement. Journal of College Student Retention: Research, Theory \& Practice, 19(3), 317-332. http://dx.doi.org/10.1177/1521025116629152

Winter, E., \& Chapleo, C. (2017). An exploration of the effect of servicescape on student institution choice in UK universities. Journal of Further and Higher Education, 41(2), 187200. https://doi.org/10.1080/0309877X.2015.1070400

Woo, K., Gosper, M., McNeill, M., Preston, G., Green, D., \& Phillips, R. (2008). Web-based lecture technologies: Blurring the boundaries between face-to-face and distance learning. Research in Learning Technology, 16(2), 81-93. https://doi.org/10.1080/09687760802315895

Young, A., \& Norgard, C. (2006). Assessing the quality of online courses from the students' perspective. Internet and Higher Education, 9(2), 107-115. https://doi.org/10.1016/j.iheduc.2006.03.001

Ziguras, C., \& McBurnie, G. (2011). Transnational higher education in the Asia-Pacific region: From distance education to the branch campus. In S. Marginson, S. Kaur, \& E. Sawir (Eds.), Higher education in the Asia-Pacific (pp. 105-122). Dordrecht: Springer.

Corresponding author: Matthew Bailey, matthew.bailey@mq.edu.au

Australasian Journal of Educational Technology (c) 2018.

Please cite as: Bailey, M., Gosper, M., Ifenthaler, D., Ware, C., \& Kretzschema, M. (2018). On-campus, distance or online? Influences on student decision-making about study modes at university. Australasian Journal of Educational Technology, 34(5), 72-85. https://doi.org/10.14742/ajet.3781 